\title{
ENCAPSULATION OF CELLS IN AGAROSE BEADS FOR USE IN THE CONSTRUCTION OF HUMAN DNA LIBRARIES AS YEAST ARTIFICIAL CHROMOSOMES (YAC)
}

\author{
Kazushige Yokoyama, Fujiko SaKa, Tatsuo KaI, \\ and Ei-ichi SoEDA* \\ Gene Bank, RIKEN (The Institute of Physical and Chemical Research), \\ Koya-dai, Tsukuba, Ibaraki 305, Japan
}

\begin{abstract}
Summary A simple and general method for the molecular cloning of fragments of over one hundred kilobase pairs of exogenous DNA, by the encapsulation of cells in agarose beads, was developed for the construction of a human genomic DNA library in a yeast artificial YAC chromosome vector (in situ YAC construction). The main advantages of this method for use in the construction of a human genome library are as follows. First, linear DNA molecules of up to several hundred kilobase pairs in size can easily be prepared by the partial restriction enzyme digestion of the DNA encapsulated in agarose beads in vitro. Second, less than $2 \times 10^{6}$ cells scraped from tissue culture plates are sufficient for preparation of the linear DNA molecule for construction of the genome library. The technical manipulations involved in construction of clones of very large segments of DNA, including encapsulation of cells in agarose beads, restriction enzyme digestion, ligation with the YAC vector, transformation into host yeast cells, and stable propagation are discussed.
\end{abstract}

Key Words agarose beads, in situ YAC construction, human genome DNA library

\section{INTRODUCTION}

A chromosome-specific ordered library would be a significant contribution toward efforts aimed at understanding the structure and function of human chromosome. If coupled to the known genetic map, such an ordered library would provide information on genetic versus physical map distances and be a source of mapped fragments for nucleotide sequencing of DNA. In attempt to prepare an ordered human chromosome library, the pulsed-field gradient gel electrophoresis (PFGE), which can separate DNA molecules of hundreds to thousands of kilobase pairs in

Received January 29, 1990; Accepted February 7, 1990.

* To whom correspondence and requests for reprints should be addressed. 
length (Schwartz and Cantor, 1984; Chu et al., 1986; Carle et al., 1986), and the yeast artificial chromosome vector (YAC) for the cloning of large fragments of human DNA have been developed (Burke et al., 1987). As a step towards the ultimate goal, a YAC was used to construct a complete human genome DNA library. Linear DNA molecules of over one hundred kilobase pairs in length from a human, normal, diploid lung-cell line, MRC-5 (Jacobs et al., 1970) have been cloned and used to transform AB1380 host yeast cells.

The refinement of several steps in the cloning procedure has improved the yield of YAC constructs, and it has increased the average size of cloned insert DNA. However, it is still necessary to use the size-selection of DNA to increase the average size of the cloned DNA inserts of YAC. The standard size-selection procedure is an elaborate step, it is time-consuming, and more than $10^{8}$ cells are required, as starting materials for the DNA (approximately $250 \mu \mathrm{g}$ ). In order to circumvent these problems, we describe a new technology for encapsulating cells in agarose beads for preparation of very large fragments of human DNA. The original method was described by Jackson and Cook (1985), for preparation of yeast cells encapsulated in agarose beads. Recently, Overhauser and Radic (1987) modified and developed this technique for the extraction of DNA from cultured cells. They prepared restriction enzyme digests of DNA in agarose beads and analyzed them by PFGE gel. We further modified this method to permit the preparation of higher-molecular-weight human DNA for molecular cloning. This technique is a very powerful and reproducible method for the preparation of DNA of very high molecular weight without shearing of the DNA during isolation. Encapsulation of cells in agarose beads increases the surface area available and allows rapid diffusion of enzymes. Therefore, shorter digestion times can be used to reduce the possibility of degradation of DNA. The precise technical manipulations of very large fragments of DNA, including the encapsulation of cells in agarose beads, enzymatic digestion, ligation and transformation are described here. These techniques allow resolution of a large range of DNA restriction fragments to be cloned in a YAC vector and the preparation of DNA of high-molecular-weight from a small number of the cells as starting material.

\section{MATERIALS AND METHODS}

Strains, vectors and tissue-cultured cells. The artificial chromosome cloning vector pYAC4 and the yeast host strain AB1380 have been described previously (Burke et al., 1987). The artificial chromosome strains HY-1 was used as a control or size marker. Yeast strains were grown non-selectively on YPD media, or they were grown selectively on single or double nutrient drop-out media as described elsewhere (Burk et al., 1987). A normal human line of diploid lung cells, MRC-5 (Cell Bank, RIKEN) was cultured in a Dulbecco's modified Eagle medium (DME) (GIBCO, Grand Island, NY.) supplemented with 10\% fetal bovine serum (FBS) (Hyclone, Logan, Utah). $1 \times 10^{7} \mathrm{MRC}-5$ cells were radiolabeled with $1 \mathrm{mCi}$ of 
$\left[{ }^{3} \mathrm{H}\right]$ thymidine $(20 \mathrm{Ci} / \mathrm{mmol})$ (Amersham, Buckinghamshire, U.K.) and both radioactivity of DNA entrapped in agarose beads and the concentration of DNA were measured for calculation of the specific activity of the DNA in the encapsulated beads.

Enzymes and chemicals. Restriction enzymes, calf intestine alkaline phosphatase (CIP phosphatase), and DNA ligase were purchased from Takara Shuzo, Kyoto and Toyobo, Inc., Tokyo. All chemicals were from Sigma Chemical Co. (St. Louis, Mo.).

Pulsed-field gel electrophoresis and Southern transfer. Samples of high-molecular-weight DNA were analyzed by pulsed-field gel electrophoresis using either of two configuration of the gel apparatus. A version of the contour-clamped homogenous electric field (CHEF) system of Chu et al. (1986) was used for samples of larger size distribution. One percent agarose gels were used in $0.5 \times \mathrm{TBE}$ running buffer, maintained at $12^{\circ} \mathrm{C}$, with a gradient of $6 \mathrm{~V} / \mathrm{cm}$, a 60 -sec switching interval, and a total run time of 18 to $24 \mathrm{hr}$. DNA molecules in an approximate size range of 20 to $1,500 \mathrm{~kb}$ are easily fractionated. Alternatively, samples of a defined size range were assayed by field-inversion gel electrophoresis (FIGE); (Carle et al., 1986). The switching regime used was a ramped forward switch time of 3 to $60 \mathrm{sec}$ and a ramped backward switch time of 1 to $5 \mathrm{sec}$, with a total run time of $17 \mathrm{hr}$. The transfer of DNA from agarose gels to nitrocellulose, and details of hybridization have been described elsewhere (Carle et al., 1986; Sherman et al., 1983).

Preparation of agarose beads containing human DNA. Cells were scraped from tissue culture plates and centrifuged at $400 \times g$ for 10 min at $4^{\circ} \mathrm{C}$. Approximately $1 \times 10^{7}$ cells were washed in cold, calcium-free, phosphate-buffered saline (PBS) and resuspended in $5 \mathrm{ml}$ PBS. The suspension of cells was placed in a water bath at $45^{\circ} \mathrm{C}$. An aliquot of $5 \mathrm{ml}$ of melted $1 \%$ low-melting-point agarose (BRL, Geithersburg, Md.) and then $20 \mathrm{ml}$ of light mineral oil (Sigma Chemical Co.) prewarmed at $45^{\circ} \mathrm{C}$, was added to the suspension of cells in agarose. The mixture was shaken vigorously for $30 \mathrm{sec}$ to generate a uniform emulsion. The emulsion was quickly poured into cold PBS with stirring. The large globules were composed of beads of $<1 \mathrm{~mm}$ in diameter. The mixture was stirred for several minutes and then transferred to several $50-\mathrm{ml}$ conical tubes and centrifuged at $400 \times g$ for $10 \mathrm{~min}$. The mineral oil at the top of each tube was removed. Usually there was a layer of agarose beads directly beneath the mineral oil and at the bottom of the tube. After centrifugation at $400 \times g$ for $10 \mathrm{~min}$, most of the beads were found in the pellet. The supernatant was removed and the inside of each tube was wiped to remove any excess mineral oil. Twenty milliliter of $1 \%$ SDS, 25 mM EDTA ( $\mathrm{pH} 8.0$ ) were added to the beads. Repeated pipetting was performed to break up any clumps and the suspension was rocked at room temperature for $10 \mathrm{~min}$. The beads were centrifuged and suspended in a mixture of $20 \mathrm{ml}$ of $1 \%$ (w/v) sarkosyl, $25 \mathrm{ml}$ of $0.5 \mathrm{M}$ EDTA ( $\mathrm{pH} 8.0$ ), $50 \mu \mathrm{g} / \mathrm{ml}$ proteinase $\mathrm{K}$ and incubated overnight at $50^{\circ} \mathrm{C}$. After digestion by proteinase $\mathrm{K}$, the beads were resuspended in $20 \mathrm{ml}$ TE $[1 \mathrm{M}$ Tris- $\mathrm{HCl}$ (pH 8.0), $1 \mathrm{~mm}$ EDTA] that contained $0.1 \mathrm{~mm}$ phenylmethylsulfonylfluoride (PMSF) 
(Sigma Chemical Co.) and dispersed well, centrifuged, and then washed several times in TE before being stored at $4^{\circ} \mathrm{C}$.

Restriction enzyme digestion of DNA in agarose beads. The concentration of DNA in the beads that contained human DNA was about 30-50 $\mu$ g DNA per 500 $\mu$ beads. Usually $500 \mu$ of the suspension of beads ( $30 \mu \mathrm{g}$ of DNA) was washed

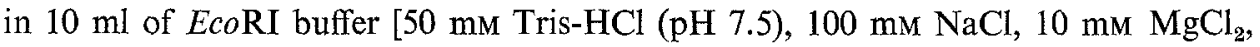
$1 \mathrm{~mm}$ DTT, Toyobo Co., Tokyo] and the enzyme concentration was adjusted to be in the range of 0.01 to 0.1 unit per digest. The total volume of the reaction mixture was $1.0 \mathrm{ml}$ and incubated for $15 \mathrm{~min}$ at $37^{\circ} \mathrm{C}$. The reactions were stopped by addition of EDTA, and the size of DNA fragments was analyzed by PFGE.

Ligation of DNA in agarose beads with the $p Y A C$ vector. The plasmid pYAC4 was digested with BamHI and EcoRI, and dephosphorylated with CIP phosphatase. The right and left arms of the pYAC4 vector were gel-purified using DE 81 paper. After mixing, vectors $(2 \mu \mathrm{g})$ and DNA in agarose beads $(6 \mu \mathrm{g})$ were brought to $1 \times$ ligation mixture (see Results AND Discussion). Then $1 \mu$ l of T4 ligase (Takara, $350 \mathrm{U} / \mu \mathrm{l}$ ) was added and the samples (total volume, $300 \mu \mathrm{l}$ ) were placed at $15^{\circ} \mathrm{C}$ for $2 \mathrm{hr}$. The suspension of ligated DNA in the agarose beads was heated at $65^{\circ} \mathrm{C}$ for $30 \mathrm{~min}$ just before the incubation with yeast spheroplasts.

Transformation of yeast spheroplasts with DNA in agarose beads. The yeast cells (AB1380) were grown overnight with vigorous aeration in $100 \mathrm{ml}$ of YPD medium to about $3 \times 10^{7}$ cells per $\mathrm{ml}$. The cells were washed successively with $20 \mathrm{ml}$ of sterile water and $20 \mathrm{ml}$ of $1 \mathrm{M}$ sorbitol (Fisher Scientific, Fair Lawn, NJ.) by centrifugation and resuspension. The cell pellets were suspended in $20 \mathrm{ml}$ SCEM [1 M sorbitol, $0.1 \mathrm{~m}$ sodium citrate ( $\mathrm{pH} 5.8$ ), $10 \mathrm{mM}$ EDTA, $30 \mathrm{~mm}$ B-mercaptoethanol (B-ME)], then $50 \mu$ of Zymolyase (Kirin, Tokyo; $10 \mathrm{mg} / \mathrm{ml}$ ) were added, and the cells were incubated at $30^{\circ} \mathrm{C}$ with occasional shaking.

The formation of spheroplasts was followed by measuring the decrease in turbidity at $800 \mathrm{~nm}$ of a 10-fold dilution of cells in water. When it was complete, cells were harvested by centrifugation for $4 \mathrm{~min}$. The following steps were carried out gently and with care. The spheroplasts were resuspended in $20 \mathrm{ml}$ of STC [1 M sorbitol, $10 \mathrm{~mm}$ Tris- $\mathrm{HCl}(\mathrm{pH} 7.5), 10 \mathrm{mM} \mathrm{CaCl}_{2}$ ] and pelleted again by centrifugation for $4 \mathrm{~min}$. The cell pellets were resuspended in $2 \mathrm{ml}$ of STC. An aliquot of $100 \mu$ of the spheroplast cell suspension was mixed with the DNA in the agarose beads that was ligated to the pYAC4 vector and the mixture was immediately heated at $65^{\circ} \mathrm{C}$ for $30 \mathrm{~min}$. Salmon sperm DNA was added as carrier to give a total 2 $\mu$ g DNA. After standing at room temperature for $10 \mathrm{~min}, 1 \mathrm{ml}$ of PEG [10 mM Tris- $\mathrm{HCl}$ ( $\mathrm{pH} 7.5$ ), $10 \mathrm{mM} \mathrm{CaCl}, 20 \%$ polyethyleneglycol 8000 (Fisher Scientific) was added. The spheroplasts were gently resuspended and harvested by centrifugation for $4 \mathrm{~min}$ after standing for another $10 \mathrm{~min}$. The pellets were resuspended in $150 \mu$ of SOS ( $1 \mathrm{M}$ sorbitol, $65 \mathrm{mM} \mathrm{CaCl}_{2}, 0.25 \%$ yeast extract, $0.5 \%$ bactopeptone) supplemented with amino acid mixtures (Sherman et al., 1983), and incubated for 30 min at $30^{\circ} \mathrm{C}$. Then, $8 \mathrm{ml}$ of TOP agarose $[1 \mathrm{M}$ sorbitol, $2.5 \%$ agarose in SD medium (Sherman et al., 1983)] which has been kept at $45^{\circ} \mathrm{C}$ were added. The contents of 
the tube were mixed gently and plated immediately on SORB plates (SD plates containing $0.9 \mathrm{M}$ sorbitol and $3 \%$ glucose) kept at room temperature. Colonies were first placed on single drop-out regeneration plates (-Ura), and then picked up on double-selection (-Ura-Trp) plates. Transformants were finally picked on -Ura. -Trp, -Arg, + canavanine plates. All media and transformation solutions have been described elsewhere (Sherman et al., 1983).

Yeast cloning, lysis, and hybridization. Yeast colonies (ura-, $\operatorname{trp}^{-}, \mathrm{ade}^{+}$) were picked up in an ordered 96-well array, immobilized and lysed on support membranes by a modification of the procedure of Grunstein and Hogness (1975). Yeast cells were inoculated onto the surface of a nylon membrane. The membrane was placed, inoculated side up, on the surface of a petridish that contained $1.5 \%$ agar. The colonies were allowed to grow overnight on YPD media, or in some cases, for 2 days on synthetic selective media. After growth, the membranes were lifted off the media and placed on Whatman $3 \mathrm{MM}$ paper that had been soaked in spheroplasting solution (SCE, $70 \mathrm{~mm}$ B-ME, 50 units $/ \mathrm{ml}$ Zymolyase). The membrane and soaked paper were incubated for $10-16 \mathrm{hr}$ at $37^{\circ} \mathrm{C}$. The spheroplasted colonies were lysed by placing the membrane, colony-side up, on a piece of Whatman $3 \mathrm{MM}$ paper soaked with $10 \%$ SDS for $3 \mathrm{~min}$. Then the membrane was placed on paper soaked with $0.5 \mathrm{~m} \mathrm{NaOH}$. The second treatment was continued for $8 \mathrm{~min}$ before the colony-bearing membrane was transferred to paper soaked with $0.5 \mathrm{M}$ Tris- $\mathrm{HCl}(\mathrm{pH} 8.0), 2 \times \mathrm{SSC}(0.15 \mathrm{M} \mathrm{NaCl}, 0.015 \mathrm{M}$ sodium citrate) for $2 \mathrm{~min}$. The membrane were then briefly rinsed in $2 \times$ SSC and left to air-dry. Such membranes can be screened directly by hybridization as describedelse where (Burke et al., 1987). A pilot screening experiment was performed using an ordered 96-well array of tested clones. The probes used to identify human cloned genomic DNA were a 280-bp BamHI fragment of BLUR-8 (Alu probe); (Deininger et al., 1981), pBR322, and human placenta genomic DNA. The probes were radiolabeled with $\left[{ }^{32} \mathrm{P}\right] \mathrm{dCTP}$ using an oligopriming labeling kit (Pharmacia-LKB, Bromma) as described by Feinberg and Volgelstein (1983).

\section{RESULTS AND DISCUSSION}

A fundamental technique has been developed which involves the encapsulation of cells in agarose beads for the isolation of DNA and the construction of human DNA libraries on a YAC vector. Figure 1 shows MRC-5 cells encapsulated in agarose microbeads. The pores in the beads are large enough to allow free exchange of proteins as large as $1.5 \times 10^{8}$ daltons in weight but not of chromosomal DNA. Therefore, when the encapsulated cells are immersed in SDS detergent solution, most cytoplasmic proteins and RNA diffuse out through the pores in the beads to leave encapsulated chromatin. In the presence of EDTA, after lysis, the resulting DNA remains intact. The procedure essentially yields a preparation of encapsulated nuclei. The main advantage of this technique, compared to other methods of extraction higher-molecular-weight DNA, is that the manipulations 


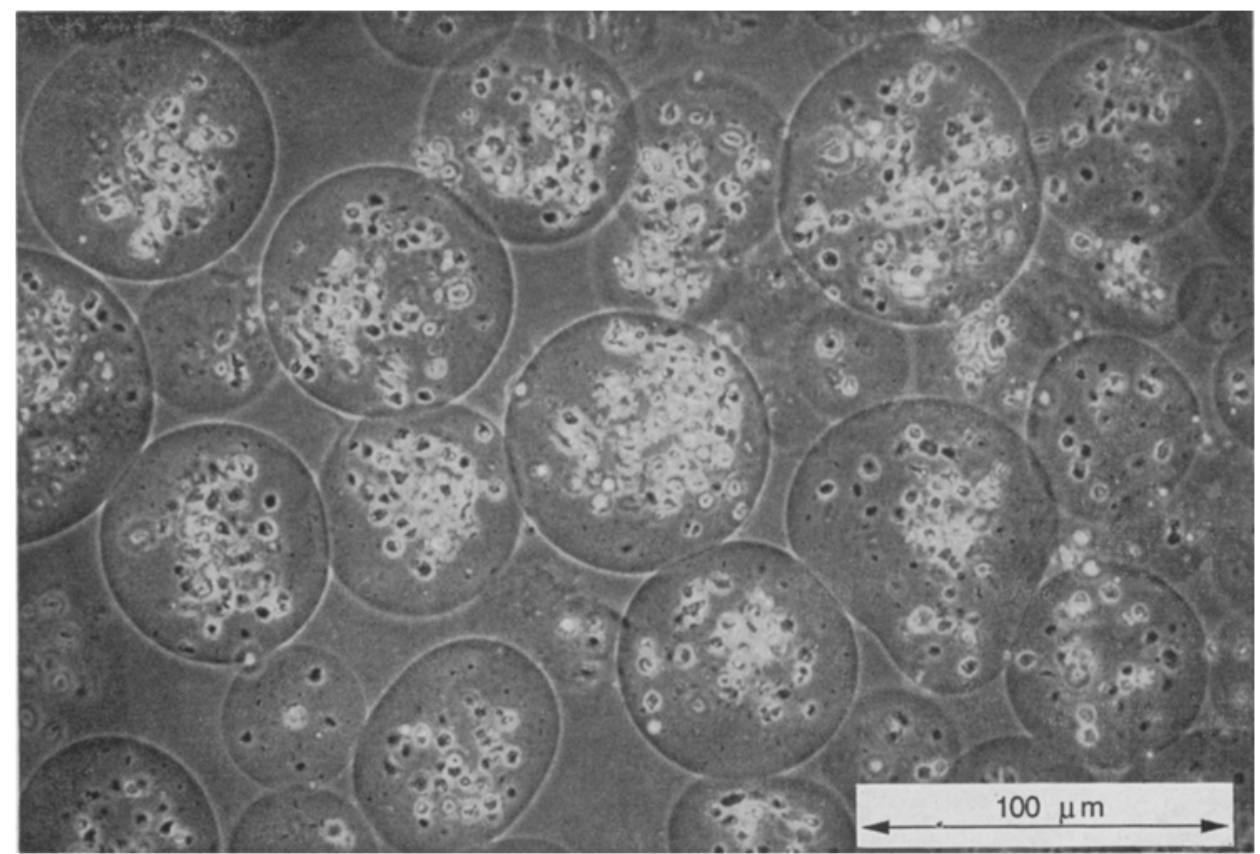

Fig. 1. Phase-constant microscopy of human MRC-5 cells encapsulated in agarose microbeads. About $75 \%$ of beads have diameters between 40 and $70 \mu \mathrm{m}$.

are very simple and the preparation of the larger fragments of DNA by restriction enzyme digestion is more reproducible. The DNA encapsulated in agarose beads is also quite stable for several months without any apparent degradation. These properties are useful for construction of human genomic libraries in conjunction with the standard molecular cloning protocol (Sherman et al., 1983; Maniatis et al., 1982).

$1 \times 10^{7}$ MRC-5 cells were radiolabeled with $1 \mathrm{mCi}\left[{ }^{3} \mathrm{H}\right]$ thymidine in DME medium and DNA of very high-molecular-weight was prepared in agarose beads. We measured the radioactivity of the DNA in the beads and the concentration of DNA to calculate the specific activity. We estimated that there were about $6.5 \mu \mathrm{g}$ of DNA per $10^{6}$ cells in agarose beads.

The partial digestion with RcoRI of human genomic DNA in the agarose beads was carried out to compare the size distribution of each digest with that from digests of the standard DNA extracted in liquid on PFGE. As shown in Fig. 2, DNA of very high-molecular-weight from the human genome, prepared in agarose beads, has a more heterogenous size-distribution, ranging from 100-1,500 kb. Furthermore it is easier, using the beads, to determine suitable conditions for digestion of human DNA with EcoRI for the generation of an appropriate size-distribution of fragments of DNA for cloning. For example, DNA from MRC-5 cells can be digested with various amounts of purified restriction endonucleases. A broad 
range of concentrations of EcoRI $(0.04-0.4 \mathrm{U} / \mu \mathrm{g})$ is optimal for such digestions (Fig. 2).

By contrast, the size-distribution of the intact human DNA extracted by the standard methods in liquid (Burke et al., 1987) is narrower, ranging from 150 to 800 $\mathrm{kb}$. A narrow range of concentrations of EcoRI $(0.02-0.04 \mathrm{U} / \mu \mathrm{g})$ is required for the optimal size-distribution of human DNA.

The construction of artificial chromosome clones in numbers sufficient for the generation of human DNA libraries has presented several problems with respect to the manipulation of DNA of high-molecular-weight. Many of the steps involve

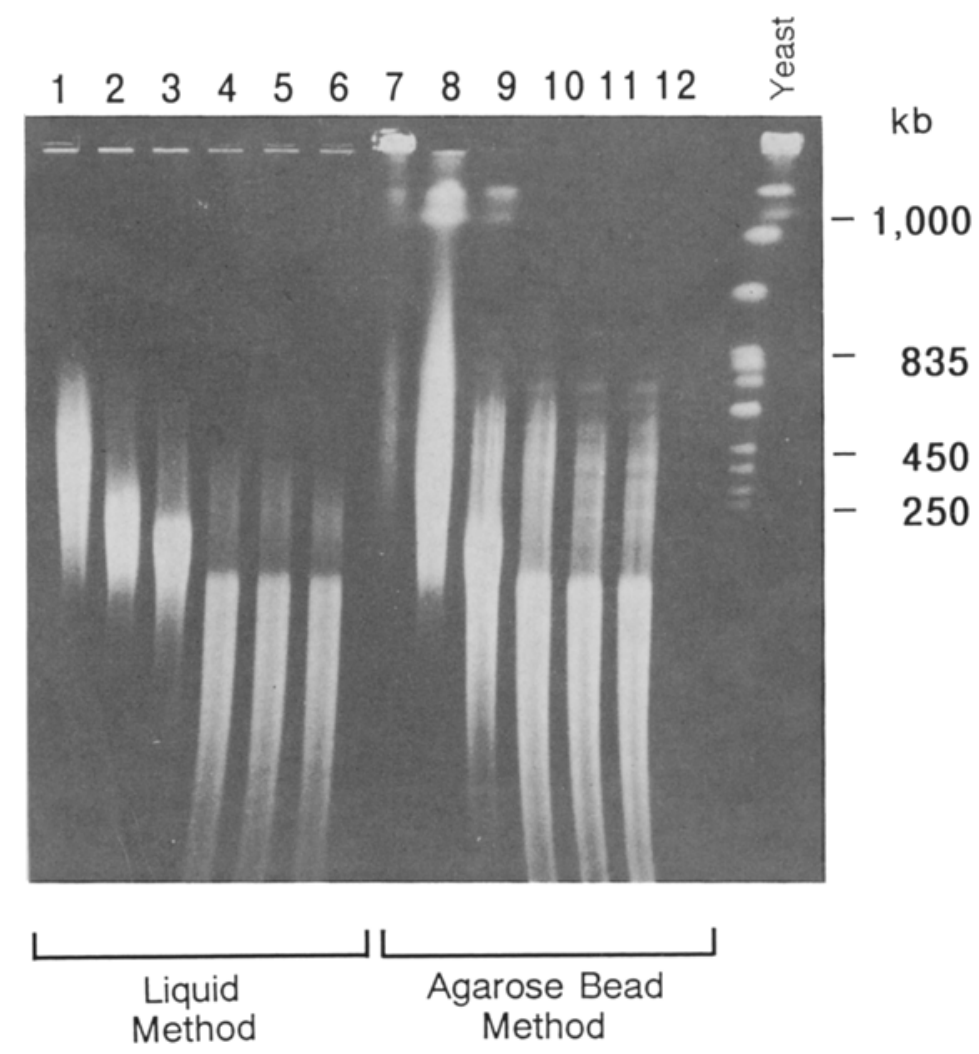

Fig. 2. Pulsed-field gel analysis of human MRC-5 genomic DNA. An ethidium bromidestained PFGE gel on which a series of sample of human DNA which were prepared by the agarose bead method and by the liquid extraction method and partially digested with $E c o$ RI, have been size-fractionated. Lanes 1 and 7 contain samples of intact DNA isolated from human MRC-5 genomic DNA. Lanes 2-6 and 8-12 show the DNA restriction digestion patterns in the increasing concentrations of $E c o$ RI: lane 2, 0.02 unit (U); lane 3, $0.04 \mathrm{U}$; lane 4, $0.4 \mathrm{U}$; lane 5, $2 \mathrm{U}$; lane 6, $4 \mathrm{U}$; lane 8, $0.04 \mathrm{U}$; lane 9, $0.4 \mathrm{U}$; lane 10, $2 \mathrm{U}$; lane 11, $4 \mathrm{U}$ and lane 12, $20 \mathrm{U}$. The reaction mixtures were incubated at $37^{\circ} \mathrm{C}$ for $15 \mathrm{~min}$. Fragment sizes for the natural yeast chromosomes are indicated at the right lane. 
a significant loss of source DNA, both because of the need to assay the DNA for size on PFGE at each step, and because of the inherent inefficiency of partial-digestion procedures. As a result, the generation of large numbers of YAC clones requires the initial preparation of $500 \mu \mathrm{g}$ of source DNA of high molecular weight for the sucrose gradient isolation procedure (Burke et al., 1987; Pete and Fangman, 1972). This step is tedious and requires considerable skill for the fractionation of the high-molecular-weight DNA.

By contrast, the manipulation of the digestion reaction using DNA in agarose beads is very simple and suitably sized, partially digested fragments of DNA are easy to obtain. The amount of DNA needed as starting material for cloning is much lower; less than approximately $50 \mu \mathrm{g}$. The strategy used for the isolation of DNA of very high-molecular-weight using agarose beads is recommended for the construction of a cloned YAC library from small amounts of DNA. A minimum number of cells, approximately $2 \times 10^{6}$ cells, was sufficient for preparing the agarose beads.

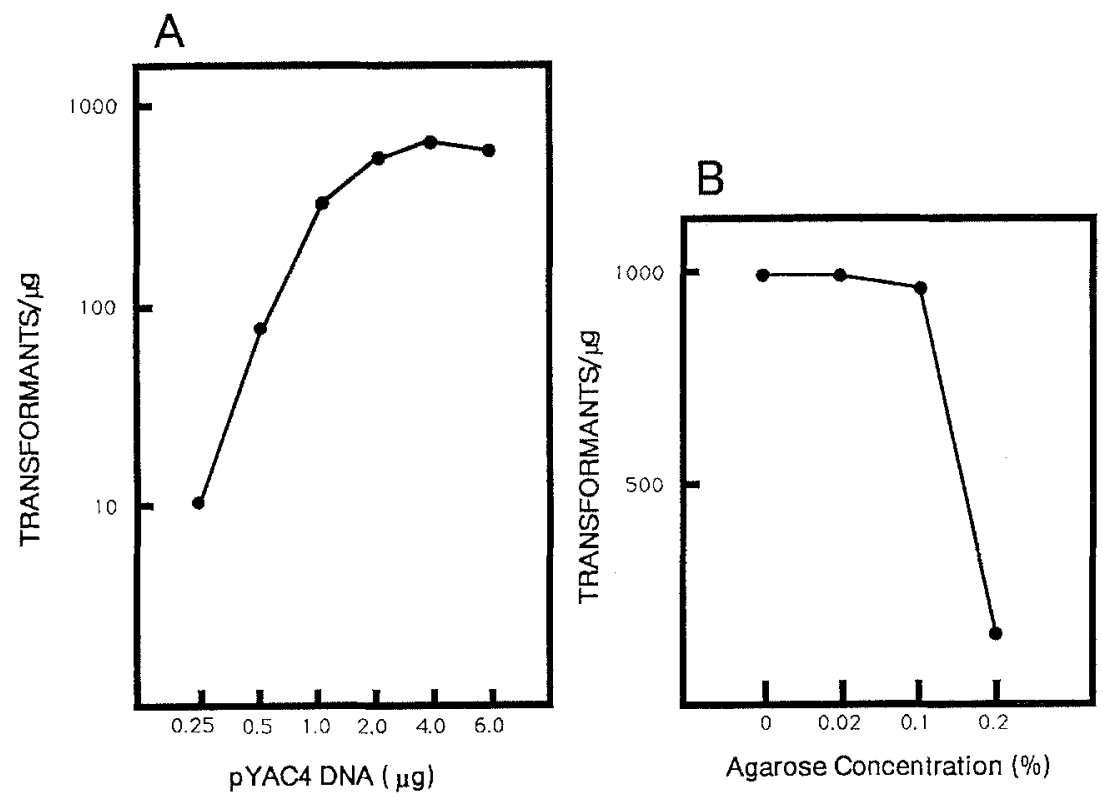

Fig. 3. Analysis of YAC ligation and transformation. A) Effect of the concentration of DNA of pYAC4 arms on transformation. Various amount of pYAC4 DNA arms $(0.25-5.0 \mu \mathrm{g})$ were ligated with $6 \mu \mathrm{g}$ of DNA in agarose beads and analyzed in terms of the transformation efficiency. AB1380 cells were spheroplasted in the usual way. Various dilutions of ligated DNA, in a less than $100 \mu \mathrm{l}$ of STC, were added to $200 \mu \mathrm{l}$ aliquots of the spheroplasts. B) Effect of the addition of melted agarose beads during the transformation. During the incubation with spheroplasts of the agarose human DNA which had been ligated with the DNA of pYAC4 arms in agarose beads, various concentration of melted agarose beads were added to the reaction mixture $(300 \mu \mathrm{l})$ and the transformation efficiency was measured. 
The partially EcoRI-digested human DNA in agarose beads was ligated to pYAC4 vector arms prepared as described in MATERIALS AND Methods and the transformation was carried out using yeast host strain AB1380 (Burgers and Percival, 1987). Various ligation conditions were analyzed in terms of the final transformation efficiency.

The pYAC4 cloning vector was prepared by complete digestion with BamHI and EcoRI, followed by treatment with CIP. Six micrograms of DNA in beads were mixed with various amounts of pYAC4 vector DNA. After mixing vector and DNA in beads, the sample was brought to $50 \mathrm{~mm}$ Tris- $\mathrm{HCl}(\mathrm{pH} \mathrm{7.5),10 \textrm {mm }}$ $\mathrm{MgCl}_{2}, 1 \mathrm{mM}$ ATP. Three hundred and fifty units of T4 DNA ligase were added and the sample was placed at $15^{\circ} \mathrm{C}$ for $2 \mathrm{hr}$. The ligation samples were washed several times with STC. The post-ligation mix was assayed by PFGE to check the extent of degradation of DNA prior to transformation.

The optimal relative concentrations of pYAC4 arms and agarose beads with DNA during ligation were tested by assessment of the transformation efficiency (Fig. 3A). Transformation frequency is very dependent on the relative concentrations of the pYAC arms and the DNA in agarose beads. More than $2 \mu \mathrm{g}$ pYAC4 arm DNA is sufficient for optimal transformation efficiency with $6 \mu \mathrm{g}$ of DNA in agarose beads, indicating that $2 \mu \mathrm{g} \mathrm{DNA}$, at least, is required for higher transformation efficiency. When the agarose beads were melted at $65^{\circ} \mathrm{C}$ for $30 \mathrm{~min}$ before ligation, the transformation efficiency decreased to $60 \%$ (data not shown). Thus, the ligation should be carried out using DNA in intact agarose beads. The most commonly employed range of concentrations of DNA in our hands is from $0.1-10$ $\mu \mathrm{g}$ of total DNA in a volume of $300 \mu \mathrm{l}$.

The transformation frequency was dependent on the concentration of spheroplasts and carrier DNA used during the transformation. The ratio of spheroplasts and the ligated human DNA-pYAC4 DNA was also critical for the highest transformation efficiency. Spheroplasting at threefold higher cell densities decreased the transformation frequency 3- to 5-fold (data not shown). The survival of spheroplasts was also reduced several-fold under these conditions. The centrifugation employed during harvesting and washing of the spheroplast led to the incomplete recovery of spheroplasts: (yield, $50-60 \%$, as determined by $A_{660}$ ). Taking into account $50 \%$ loss mentioned above, the plating efficiency of spheroplasts treated with DNA and PEG was usually 50-70\%. Optimal efficiency of transformation was obtained with about $3 \times 10^{8}$ spheroplasts $/ \mathrm{ml}$ and $2 \mu \mathrm{g}$ of carrier DNA. The maximum percentage of transformable cells is constant at concentrations of spheroplast up to $3 \times 10^{8} / \mathrm{ml}$ but then decreases dramatically. Ligation volume of more than $300 \mu$ decreased the transformation efficiency, 8- to 9-fold. The ligation temperature of $15^{\circ} \mathrm{C}$ is also critical (data not shown).

Efficient transformation of yeast spheroplasts required the care be taken at several stages of the procedure. It is essential that the spheroplasts should be maintained in a hyper-osmotic environment, usually $1 \mathrm{M}$ sorbitol. At this high concentration of sorbitol, minor chemical contaminants in the sorbitol can have 
serious effects on spheroplast viability and transformation efficiency. All solutions and growth media should be prepared with high-quality sorbitol.

The melting of the ligated DNA-agarose beads during the transformation is critical for maximum transformation. The presence of non-melted agarose beads after ligation decreased the transformation efficiency to about $50 \%$. The concen-
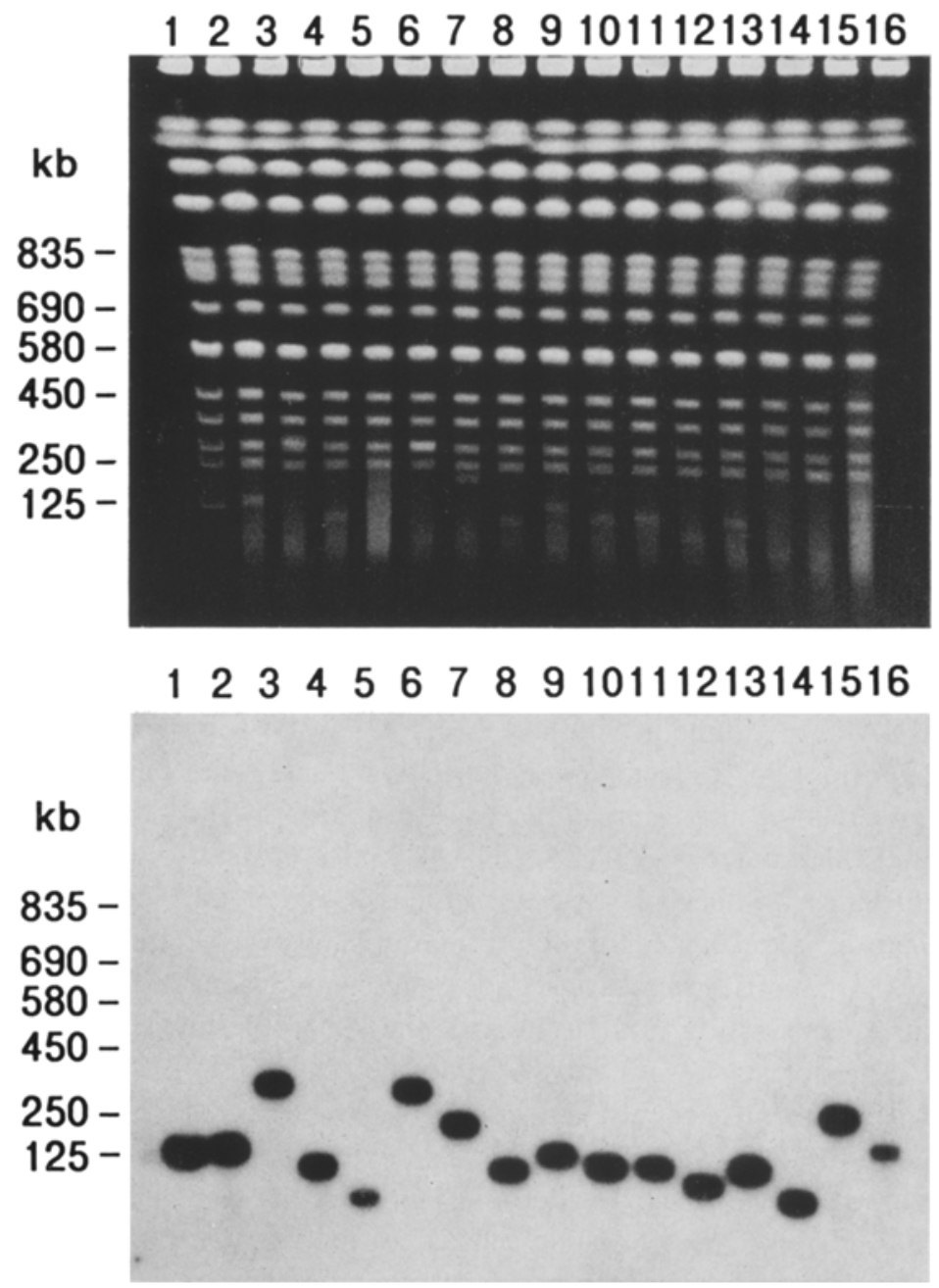

Fig. 4. Size-distribution of YAC clones from the human MRC-5 DNA encapsulated in agarose beads. An autoradiogram showing the artificial chromosomes maintained in 15 randomly chosen clones (lanes 2-16). Lane 1 shows HY1 which contains a $125 \mathrm{~kb}$-insert derived from the DNA of CGM1 cells (EB virus-transformed, human peripheral lymphocyte cells). The artificial chromosomes were size-fractionated by PFGE and are visualized by hybridization to their pBR322derived sequences. 
tration of the melted agarose beads is also critical. The ligated samples of human genomic DNA and pYAC4 vector arms were mixed at various concentration of melted agarose beads during transformation. Figure 3B shows how the increasing concentration of the melted agarose beads decreases transformation efficiency. More than $0.12 \%$ agarose in the transformation mixture has a drastic negative effect. Although we do not know the reasons for the decrease in the efficiency of transformation, the agarose might cause a change in the osmotic environment of yeast spheroplasts. One must be very careful to keep the agarose concentration below $0.12 \%$ during the incubation with spheroplasts for transformation.

Under optimal transformation conditions, the transformation of yeast spheroplasts generated approximately $10^{4}$ clones per microgram of DNA. The total

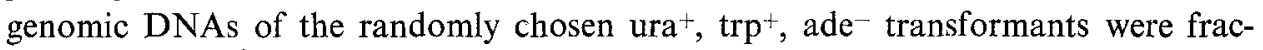
tionated on PFGE, blotted on the nitrocellulose and hybridized with a radiolabeled human repetitive Alu sequence probe (Deininger et al., 1981), and with radiolabeled pBR322 and human genomic DNA probes. One of these analyses is shown in Fig. 4 of the primary ura $^{+}, \operatorname{trp}^{+}$transformants, over $95 \%$ of the isolates were also $\mathrm{ade}^{-}$(red). The sizes of the inserted DNA in the YAC clones were estimated as illustrated in the histogram in Fig. 5. The DNA prepared from these clones had a heterogenous size-distribution, ranging from $60-200 \mathrm{~kb}$. The average size was approximately $120-130 \mathrm{~kb}$. Although the exact reasons for the small inserts being cloned are not clear, one of the explanations might be the higher molar con-

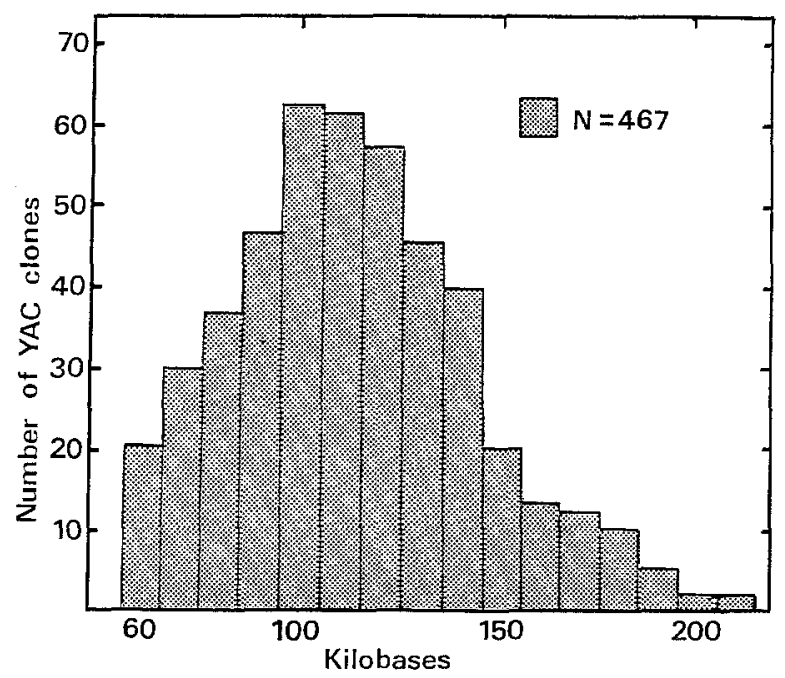

Fig. 5. Histograms of the size-distribution of DNA from the human chromosome pool. Random transformants from each of the ligations were size-fractionated on pulsedfield gels, transferred to nitrocellulose, and hybridized with radiolabeled pBR322 or human Alu DNA probe. Sizes of artificial chromosome were determined relative to the natural yeast chromosome as standard. The sizes are plotted in terms of numbers of clones. 
centration of the small insert DNA $(120-130 \mathrm{~kb})$ than that of large DNA inserts. Thus it is highly possible that the small insert DNA $(120-130 \mathrm{~kb})$ was cloned selectively into YAC vector. Another possibility is the release of the entrapped endogenous nucleases and the physical breakage of DNA. However, we can exclude this latter possibility because the non-uniform DNA termini are not expected to ligate as efficient as ends produced by endonucleolytic cleavage. Sucrose gradient centrifugation to remove smaller fragments of DNA and non-ligated fragments after ligation reaction might improve the overall size-average of the YAC pools (unpublished data). The human genome has been estimated to contain $3 \times 10^{9}$ base-pairs of DNA per haploid genome equivalent (Kornberg, 1980). Over 5,000 colonies were isolated and stored as individual isolates at $-80^{\circ} \mathrm{C}$ in $15 \%$ glycerol. At an average of $125 \mathrm{~kb}$ of cloned human DNA per isolate, these strains represent $3.1 \times 10^{8}$ base-pairs of DNA, or approximately $20-30 \%$ of a genome equivalent.

In conclusion, a procedure has been developed for the efficient transformation of yeast spheroplasts and the isolation of DNA. The most important aspects of this procedure for achieving high efficiency are as follows: (1) Analyses of partial digestions, with restriction enzyme are necessary each time to generate an appropriate size-distribution of human DNA. (2) The relative ratio of DNA in agarose beads and pYAC4 vectors shows to be $3: 1$. (3) The ligation volume shows not exceed $300 \mu 1$. (4) A high concentration of Zymolyase is necessary to achieve rapid spheroplasting, and spectrophotometric determination of the optimal level of spheroplasting must be performed. A decrease of $85-90 \%$ in the absorption at $A_{600}$ in $15 \mathrm{~min}$ is optimal. (5) Optimal efficiency of transformation is about $3 \times 10^{8}$ spheroplasts/ml with $2 \mu \mathrm{g}$ of carrier DNA. (6) The concentration of melted agarose during transformation shows not exceed $0.12 \%$.

The advantages of this agarose bead method for construction of genomic libraries are that the smaller amounts of DNA are sufficient for the preparation of genomic DNA; each procedure is very simple and approximately $120-130 \mathrm{~kb}$ of human DNA are cloned in each member of the YAC cloned library with high reproducibility. The ability to isolate and amplify large DNA molecules in a simple genetic background would complement this powerful analytical technique and set the stage for expanded structural and functional studies of complex DNA.

Acknowledgments We thank Drs. M. V. Olson and T. Imai for providing pYAC4 and AB1380 and helpful discussion.

This work was supported by the grants from the Life Science Research Project of RIKEN.

\section{REFERENCES}

Burgers, P.M. and Percival, K.J. 1987. Transformation of yeast spheroplasts without cell fusion. Anal. Biochem. 163, 391-397.

Burke, D.T., Carle, G.F. and Olson, M.V. 1987. Cloning of large segments of exogenous DNA into yeast by means of artificial chromosome vectors. Science 236: 806-812.

Carle, G.F., Frank, M. and Olson, M.V. 1986. Electrophoretic separations of large DNA molecules by periodic inversion of the electric field. Science 232: 65-68. 
Chu, G., Vollrath, D. and Davis, R.W. 1986. Separation of large DNA molecules by contourclamped homogeneous electric fields. Science 234: 1582-1585.

Deininger, P.L., Jolly, D.J., Rubin, C.M., Friedmann, J. and Schmid, C.W. 1981. Base sequence studies of 300 nucleotide renatured reported human DNA clones. J. Mol. Biol. 151: 17-33.

Feinberg, A.P. and Volgelstein, B. 1983. A technique for radiolabeling DNA restriction endonuclease fragments to high specific activity. Anal. Biochem. 132: 6-13.

Grunstein, M. and Hogness, D. 1975. Colony hybridization: a method for the isolation of cloned DNAs that contain a specific gene. Proc. Natl. Acad. Sci. U.S.A. 72: 3961-3965.

Jackson, D.A. and Cook, P.R. 1985. A general method for preparing chromatin containing intact DNA. EMBO J. 4: 913-918.

Jacobs, J.P., Jones, C.M. and Baille, J.P. 1970. Characteristics of a human diploid cell designated MRC-5. Nature 227: 168-170.

Kornberg, A. 1980. DNA Replication, W.H. Freemen, San Francisco.

Maniatis, T., Fritsch, E.F. and Sambrook, J. 1982. Molecular Cloning : a Laboratory Manual, Cold Spring Harbor Laboratory, Cold Spring Harbor, NY.

Overhauser, J. and Radic, M. 1987. Encapsulation of cells in agarose beads for use with pulsedfield gel electrophoresis. Focus 9: 8-9.

Tete, T. and Fangman, W. 1972. Sedimentation properties of yeast chromosomal DNA. Proc. Natl. Acad. Sci. U.S.A. 69: 1188-1191.

Schwartz, D. and Cantor, C.R. 1984. Separation of yeast chromosome-sized DNAs by pulsedfield gradient gel electrophoresis. Cell 37: 67-75.

Sherman, F., Fink, G. and Hicks, J. 1983. Methods in Yeast Genetics, Cold Spring Harbor Laboratory, Cold Spring Harbor, NY. 